\title{
READING LAW AND IMAGINING JUSTICE IN THE WAHKOHTOWIN CLASSROOM
}

\section{Sarah Buhler*}

This article analyzes an innovative community-based educational project called the "Wahkohtowin class" in Saskatoon, Saskatchewan. The class brings together former gang members, Indigenous high-school students and university students from the disciplines of law, English, and Indigenous studies to learn together about law, justice, and injustice. Students in the class read legal texts together and then discuss and critique these texts in the context of the lived experiences of people in the class. Drawing on the experience of the Wahkohtowin project, this article argues that the practice of lawyers and law students reading and interpreting legal texts and talking about justice together with members of marginalized communities is an "access-to-justice innovation." It is an innovation because it is a model that positions lawyers and law students not as experts but, rather, as co-learners and co-creators of knowledge with people who possess important lived experiences of the impacts of law and the justice system. It resists the notion that the legal system or lawyers possess a monopoly on justice, opening space for lawyers, law students, and community members to imagine justice together. Overall, this article argues that it is important for those within the legal system who are seeking to improve access to justice to engage with, and learn from, members of marginalized communities who have direct experience with the justice system and that the Wahkohtowin class is one example of how this can happen.

Dans cet article, l'auteure analyse un projet éducatif communautaire innovateur appelé la "Wahkohtowin class" (classe de Wahkohtowin), qui se déroule à Saskatoon, en Saskatchewan. La classe regroupe d'anciens membres de gangs, des étudiants autochtones de niveau collégial et des étudiants universitaires issus des disciplines du droit, de l'anglais et des études autochtones, qui sont appelés à se familiariser ensemble avec divers aspects du droit, de la justice et des injustices. Les étudiants ainsi réunis lisent ensemble des textes juridiques et en discutent en relatant des expériences qu'ils ont eux-mêmes vécues. En se fondant sur l'expérience du projet Wahkohtowin, l'auteure affirme que le fait de réunir des avocats et des étudiants en droit pour qu'ils lisent et interprètent des textes juridiques et parlent de la justice avec des membres des collectivités marginalisées représente une innovation en matière d'accès à la justice. C'est là une démarche innovatrice car, dans le cadre de ce processus, les avocats et les

Associate Professor at the University of Saskatchewan College of Law. I acknowledge with gratitude my University of Saskatchewan colleagues Priscilla Settee and Nancy Van Styvendale and my STR8 UP and Oskayak High School colleague Stan Tu'Inukuafe. The Wahkohtowin class project and research was funded by a Social Sciences and Humanities Research Council Partnership Grant entitled "Urban Aboriginal Knowledge Network: Research for a Better Life." The funding was administered by the Prairie Research Centre of the Urban Aboriginal Knowledge Network. I also acknowledge the helpful comments of the anonymous reviewers of this article. 
étudiants en droit sont présentés, non pas comme des spécialistes, mais comme des coapprenants et des cocréateurs de connaissances qui ont la chance de côtoyer des personnes ayant vécu des expériences marquantes dans le cadre de leurs démêlés avec la loi et le système de justice. Le projet va à l'encontre de l'idée selon laquelle le système de droit ou les avocats possèdent un monopole sur la justice, permettant ainsi d'entrevoir un espace dans lequel les avocats, les étudiants en droit et les membres de la collectivité pourraient imaginer la justice ensemble. De l'avis de l'auteure, il est important que les intervenants $d u$ système de justice qui s'efforcent d'améliorer l'accès à la justice s'intéressent de près aux membres des collectivités ayant vécu une expérience directe dans le cadre du système de justice et tirent des enseignements de ces contacts; le projet Wahkohtowin montre comment cette forme d'apprentissage est possible.

\section{INTRODUCTION}

In this article, I discuss an innovative community-based educational project that three colleagues and I facilitate in Saskatoon, Saskatchewan. The project is a semester-long class, called Wahkohtowin (or "kinship" in Cree), that brings together former gang members, Indigenous high-school students and university students from the disciplines of law, English, and Indigenous studies to learn together about law, justice, and injustice. One of our key activities is to read legal texts together and then to discuss and critique these texts in the context of the lived experiences of people in the class. Drawing on the experience of the Wahkohtowin project, I argue in this article that the practice of lawyers and law students reading and interpreting legal texts and talking about justice together with members of marginalized communities is an "access-to-justice innovation." It is an innovation because it is a model that positions lawyers and law students not as experts but, rather, as co-learners and co-creators of knowledge with people who possess important lived experiences of the impacts of law and the justice system. It resists any notion that the legal system or lawyers possess a monopoly on justice, opening space for lawyers, law students, and community members to imagine justice together. Overall, this article argues that it is important for those within the legal system who are seeking to improve access to justice to engage with, and learn from, members of marginalized communities who have direct experience with the justice system and that the Wahkohtowin class is one example of how this can happen.

The article proceeds in several parts. I first describe and situate the Wahkohtowin class. I then turn to a discussion of the significance of creating space for lawyers and law students to learn about law, justice, and injustice with members of communities outside of the legal field and especially with marginalized communities. I then reflect on some of the insights that this practice has opened up in the case of the Wahkohtowin class. These insights include a profound critique of the privileged position of law's dominant interpretive community, a deeper understanding of the impact of law on the lives of marginalized community members, and ideas about how legal system "insiders" can better connect with community justice priorities. I argue that from the vantage point of the Wahkohtowin classroom, it has become apparent that meaningful access to justice, especially when it comes to justice for marginalized communities, requires learning about the meaning and content of justice in these communities. This work is most meaningful when it is grounded in place, relationships, and a commitment to reciprocity. 


\section{THE WAHKOHTOWIN CLASS}

Priscilla Settee, a professor in the University of Saskatchewan's Indigenous Studies; Nancy Van Styvendale, a professor in the Department of English at the University of Saskatchewan; Stan TuInukuafe, a social worker at Oskayak High School and co-founder of STR8 UP; and I developed and facilitate the Wahkohtowin class. ${ }^{1}$ The class has had three iterations (in 2013, 2014, and 2016). It brings together law, English, and Indigenous studies students from the University of Saskatchewan, highschool students from Oskayak High School (Saskatoon's only Indigenous high school), ${ }^{2}$ and former gang members who are members of STR8 UP (a gang prevention and gang exiting organization in Saskatoon). ${ }^{3}$ Over the course of an academic semester, we meet for three hours each week in a classroom at Station 20 West, a local community enterprise centre. ${ }^{4}$ In this article, I focus my reflections and discussion specifically on the Wahkohtowin class that took place in 2014. This is because my cofacilitators and I conducted an evaluation following the completion of that class, including qualitative interviews with the participants. The comments and feedback we received as part of that evaluation inform my reflections and analysis in this article, and I include quotes from the interviews throughout the article. ${ }^{5}$

Our 2014 class was comprised of six university students (two each from law, Indigenous studies, and English), four Oskayak High School students, and five members of STR8 UP. Two of the STR8 UP participants were serving life sentences at Willow Cree Healing Lodge, a federal minimum security facility located outside of Saskatoon. We were fortunate to obtain permission for them to join us each week, along with their corrections escort. Thus, with the four facilitators, there were twenty of us

1 We have reflected previously on the pedagogy, methods, and outcomes of the class. See Sarah Buhler, Priscilla Settee \& Nancy Van Styvendale, "Teaching and Learning about Justice through Wahkohtowin" (2014) 4 Annual Review of Interdisciplinary Justice Research 182 [Buhler, Settee \& Van Styvendale, "Teaching and Learning"]; Sarah Buhler, Priscilla Settee, and Nancy Van Styvendale, “'We Went in as Strangers, and Left as Friends': Building Community in the Wahkohtowin Classroom" (2015) 1 Engaged Scholar Journal 96 [Buhler, Settee \& Van Styvendale, "We Went in as Strangers"]. We also introduce and locate ourselves individually and as a team in some detail in these articles. I am mindful that it is important to situate oneself in any research or teaching project: "Students must be told who instructors are, where they come from, and any biases they might hold. This presentation of the instructor a subjective self is important and must not be glossed over, give the colonial past and present." Lisa Monchalin, The Colonial Problem: An Indigenous Perspective on Crime and Injustice in Canada (Toronto: University of Toronto Press, 2016) at xvii. I am a white, Mennonite settler, Canadian scholar and legal educator whose grandparents settled north of Saskatoon on Treaty 6 territory. I write from my limited perspective and with appreciation for many colleagues and friends who I learn from every day.

2 Oskayak High School (formerly Joe Duquette High School) has a significant history within Indigenous education initiatives in Saskatchewan and Canada. See e.g. Celia Haig-Brown, ed, Making the Spirit Dance Within: Joe Duquette High School and an Aboriginal Community (Toronto: Lorimer, 1997). Priscilla Settee also discusses Oskayak High School. Priscilla Settee, Pimatisiwn: the Good Life, Global Indigenous Knowledge Systems (Vernon, BC: J Charlton Publishing, 2013) at 113-114 [Settee, Pimatisiwn].

3 See STR8 UP, online: <http://www.str8-up.ca>; see also STR8 UP: Stories of Courage: A Healing Workbook by Recovering Gang Members and Addicts (Saskatoon: Hear My Heart Books, 2015).

4 See Station 20 West, online: <http:/www.station20west.org>.

5 For a description of the research methodology, see Buhler, Settee \& Van Styvendale, "We Went in as Strangers," supra note 1 at 101-102. Transcripts of interviews on file with author. 
altogether. In addition to its great diversity with respect to life experiences, the group was also diverse in terms of age, ranging from teenage high-school students to our oldest student - a STR8 UP member who had spent the majority of the past fifty years in prison. Significantly, more than half of the group (all of the STR8 UP members, all of the Oskayak students, two of the university students, and two of the facilitators) identified as Indigenous. Of the remaining seven participants, one identified as South Asian, one identified as Chinese Canadian, and the others as white.

The class was born as a result of pre-existing relationships between the four facilitators. All four of us had individual relationships with each other and histories of working together on various community initiatives and projects, but we had never all worked together on a shared project. We wanted to bring our mutual interests in education, community, and justice issues together in a community-based class. We believed the class would be of interest and benefit to the university students because it would provide them with a unique opportunity to learn alongside people with different life experiences and circumstances and in a setting that was very different from the usual university classroom. Our community partner, Stan, saw the class as a benefit to the Oskayak High School students because it would expose them to a university-level educational opportunity and would allow them to test their interest in post-secondary studies. Finally, Stan wanted STR8 UP to be involved because he saw the class as connecting to STR8 UP's ongoing healing programming and also as providing STR8 UP members with a chance to learn about and demystify the dominant legal system. ${ }^{6}$ It was also an opportunity for STR8 UP members to test their interest in post-secondary education. In this way, everyone who came to the table in the Wahkohtowin class had something to gain from their participation. As one STR8 UP member explained, he joined the class because he wanted to "teach and learn" and to "bring things to the table from behind the [prison] wall." We were unable to secure university credit for the class, but this continues to be a long-term goal of our collaboration and this project.

The Nehiyaw/Cree concept of wahkohtowin was foundational to our pedagogy and method in the class. As explained by co-facilitator Priscilla Settee, the concept of wahkohtowin connotes relationship and family, even beyond blood ties. ${ }^{7}$ Settee has also explained that wahkohtowin has at its heart "the betterment of all our relations and our extended communities." ${ }^{\prime 8}$ Similarly, Sylvia McAdam (Saysewahum) explains: "wâkohtôwin ... is used to describe the kinship connections to all of creation, such as the various clan systems that create kinship responsibilities to the animals and to creation in general." The concept of relationship with other human beings as well as with the land and the value of

6 Our community partner Stan Tu'Inukuafe, a co-founder of STR8 UP and social worker at Oskayak High School, played a key role to ensure that the course was created to be beneficial to Oskayak and STR8 UP participants. As David Sandomierski has written, "[a] source of law's mystique is the sense that only the technically trained can truly engage with law." David Sandomierski, "Legal Inquiry: A Liberal Arts Experiment in Demystifying Law" (2014) 29 CJLS 311 at 315. See generally also James Boyd White, "The Invisible Discourse of the Law: Reflections on Legal Literacy and General Education" (1983) 54 U of Colorado L Rev 143.

7 See Priscilla Settee, "Learning from the Indigenous Global South" in G Dei, ed, Indigenous Philosophies and Critical Education: A Reader (New York: Peter Lang, 2011) 434.

8 Settee, Pimatisiwn, supra note 2 at 7.

9 Sylvia McAdam (Saysewahum), Nationhood Interrupted: Revitalizing Nêhihaw Legal Systems Saskatoon (Saskatoon: Purich, 2015) at 60. 
wahkohtowin was one that guided our project throughout. Thus, we centred on Indigenous pedagogies (led by the Indigenous faculty members of our group) and consciously challenged dominant approaches to pedagogy and ways of knowing. ${ }^{10}$

The Wahkohtowin class was also inspired and shaped by the Inside-Out model of communityengaged teaching and learning. Founded by Lori Pompa, the Inside-Out education model involves university students taking academic classes inside prisons alongside incarcerated men and women. ${ }^{11}$ As Simone Davis and Barbara Roswell have written, the Inside-Out model

begins with the assumption that all human beings - whether they reside behind bars or on the outside, - have innate worth, a story to tell, experiences to learn from, perspectives that provide insight, and leadership to contribute to the community ... the Inside Out model is rooted in reciprocity, dialogue, and collaboration. ${ }^{12}$

Similarly, the Wahkohtowin class is premised on the idea that each participant's experience and knowledge is valuable and that everyone has something important to bring to the table; that everyone is there to teach and to learn. Indeed, we considered class members' experiences to be core "texts" in the class alongside the legal and literary texts that we read. ${ }^{13}$ As my collaborators and I have reflected elsewhere, we "embraced the notion that rich critique and production of knowledge can occur when a diverse group thinks through issues together." ${ }^{, 14}$ One of our law students explained that the class took the view that "[e]xperience is a reasonable place to glean knowledge and discern knowledge and produce it." A STR8 UP member explained, "if we're all coming from the same place, how are you really learning anything?"

The focus of the Wahkohtowin class was the subject of justice, discussed through five different themes: policing, the criminal trial, prisons, restorative justice, and missing and murdered Indigenous women. Each class proceeded similarly. We started each day with a meal and sometimes a smudge and focused on building a sense of relationship and community. Sitting in a circle around a large table, we commenced with an "opening round." Each member of the group shared in turn about their week and their reflections from the previous week. We then turned to the topic of the day. Our method was to read legal and literary texts pertaining to the chosen topic and then analyze and examine these texts in light of

10 For more discussion of Indigenous and decolonizing pedagogies, see Marie Battiste, Decolonizing Education: Nourishing the Learning Spirit (Saskatoon: Purich Publishing, 2013); see also Monchalin, supra note 1 at xxvii. Monchalin writes that "[u]sing Indigenous teaching methods, such as storytelling and sharing circles, is also an act of decolonization."

11 For a book that discusses the Inside Out model, see Simone W Davis \& BS Roswell, eds, Turning Teaching Inside-Out: A Pedagogy of Transformation for Community-Based Education (New York: Palgrave McMillan, 2013) [Davis \& Roswell, Turning Teaching Inside-Out].

12 Simone W Davis \& BS Roswell, "Radical Reciprocity: Civic Engagement from Inside-Out" in Davis \& Roswell, Turning Teaching Inside-Out, supra note 11, 1 at 3.

13 Another interesting example of a somewhat similar approach in a different context is described by Laura Ruth Johnson \& Enid Marie Roasio-Ramos, "The Role of Educational Institutions in the Development of Critical Literacy and Transformative Action" (2012) 51 Theory into Practice 49 at 53.

14 Buhler, Settee \& Van Styvendale, "We Went in as Strangers," supra note 1 at 98. 
the experiences of the people in the class. Our legal texts included the Saskatoon panhandling bylaw, ${ }^{15}$ the sentencing provisions in section 718 of the Criminal Code of Canada, ${ }^{16}$ the decision of the Supreme Court of Canada in R. v Gladue, ${ }^{17}$ and section 31 of the Corrections and Conditional Release Act on administrative segregation/ solitary confinement in federal prisons. ${ }^{18}$ Each day we also included a literary text that connected to the legal text and topic of the day. ${ }^{19}$

We would read the texts together in small groups or individually. We then entered into another round, and each member of the class discussed in turn his or her personal experience or reflections relating to the legal text. Thus, for example, when we read section 31 of the Corrections and Conditional Release Act, each member of the class shared his or her experience, knowledge, and reflections on solitary confinement. Almost all of the STR8 UP members brought their own experiences of solitary confinement to the table; the majority of the university students in contrast had not been inside a prison but had impressions formed through their exposure to media, movies, and reading. Several of the Indigenous high-school and university students had family members who had experienced imprisonment and solitary confinement. As will become apparent, the lived experiences of STR8 UP members deeply informed the approach that the group ultimately took to its reading and interpretation of the issues and texts under discussion.

We chose to introduce primary, Canadian legal texts as core texts for the class for several reasons. First, these texts formally authorize in various ways the ability of the state agents, including judges, police officers, and correctional officers, to assert authority over the lives of people and to move their bodies through the landscape of the criminal justice and carceral systems. Because we knew that many members of our class had direct, lived experience of policing, arrest, criminal trials, incarceration, and solitary confinement, these were texts that they had "encountered" without having ever seen them. On the other hand, we knew that many of our university students (and, in particular, the law students in the class) may have heard of, or even read, the legal texts without having considered the ways in which they operate beyond the page. Thus, we believed that reading these legal texts together as a group could open up meaningful and critical discussions about the way law acts upon the lives and bodies of people and about what justice might demand from legal systems. As I discuss below, this is indeed what transpired in the Wahkohtowin class, causing me to reflect on the significance of this model for a deeper and more critical engagement by legal system insiders with access-to-justice issues facing marginalized communities.

15 City of Saskatoon Bylaw no 7850, the Panhandling Bylaw (1999), online: <https://www.saskatoon.ca/sites/default/files/documents/city-clerk/bylaws/7850.pdf

16 RSC 1985, c C-46.

17 [1999] 1 SCR 688.

18 SC 1992, c 20.

19 For more details, see Buhler, Settee \& Van Styvendale, “Teaching and Learning," supra note 1. 


\section{LEARNING TOGETHER ABOUT LAW AND JUSTICE: THE SIGNIFICANCE OF PLACE AND RELATIONSHIP}

This article is informed by Nancy Cook's critique of dominant models of access to justice. Cook explains that "access" is usually presumed by legal system "insiders" to go in only one direction towards the formal legal system, where "justice" is thought to reside. ${ }^{20}$ In this dominant conception, lawyers are envisioned as guides helping to shepherd clients into the system and provide knowledge about law and the system to those who are seeking access. ${ }^{21}$ Most current Canadian access-to-justice initiatives and innovations continue to be rooted in this "one-way-street" paradigm. These include initiatives seeking to reduce the barriers to legal assistance and representation, initiatives seeking to make legal processes more user-friendly, and many public legal education initiatives.

Of course, these "one-way-street" models of access to justice are important. Indeed, because members of marginalized communities so often find themselves in contact with the justice system when facing risk of loss (of housing, income, children, liberty), traditional forms of assistance are important. ${ }^{22}$ However, as Cook writes, when it comes to members of marginalized communities, most of these access-to-justice initiatives do not do much more than help people "stay out of harm's way" while in the territory of the judicial system. ${ }^{23}$ As critical Indigenous scholars and others have pointed out, the justice system, and, in particular, the criminal justice system, is a colonial system that sustains and reproduces harm towards Indigenous people and members of marginalized communities. ${ }^{24}$ With this in mind, it becomes apparent that many access-to-justice initiatives constitute forms of harm reduction (or "damage control" in Cook's words) ${ }^{25}$ but are not inherently transformative in terms of their ability to promote greater justice for communities.

The "one-way-street" vision of access to justice also overwhelmingly fails to consider that the legal system and those who work within it have much to learn from communities and people who are impacted by the justice system. As Austin Sarat has written, members of communities who are constantly interacting with law and legal institutions as the subjects of these institutions have access to deep knowledge about the operation and impact of the system. ${ }^{26}$ This specific, experiential knowledge may not be easily available or obvious to members of the legal community.

However, finding common space for members of the legal community and members of marginalized communities to come together in meaningful ways can be challenging. While the legal profession in Canada has become much more diverse in recent years, it is still the case that the majority of Canadian judges, lawyers, and officials who design and manage the justice system do not have direct lived

Nancy Cook, "Looking for Justice on a Two-Way Street” (2006) 20 Wash UJL Pol’y 169 at 169.

Ibid at 170 .

Ibid.

Ibid.

See e.g. Monchalin, supra note 1; Austin Sarat, "Situating Law between the Realities of Violence and the Claims for Justice" in Austin Sarat, ed, Law, Violence, and the Possibility of Justice (Princeton, NJ: Princeton University Press, 2001) 3 .

25 Cook, supra note 20 at 170.

26 Austin Sarat, "'The Law Is All Over': Power, Resistance and the Legal Consciousness of the Welfare Poor" (1990) 2 Yale JL \& Human 343 at 346. 
experience of criminalization, poverty, and racism and may be disconnected from the realities and knowledge held within socially and economically marginalized communities. ${ }^{27}$ The reality remains that while law schools and the profession have become more diverse in many important ways, access to the profession remains particularly difficult for people who are socio-economically marginalized. As Darcel Bullen and Lorne Sossin have recently written, "[w] hile Canadian legal education has shed many of the explicit trappings of exclusion steeped in racism and religious intolerance, the barriers of entry to socioeconomically disadvantaged students remain salient." ${ }^{28}$ Furthermore, the process of legal education can function to cut students off from their prior commitments and identities "in ways that subvert counter-hegemonic consciousness and the conditions that sustain it." 29 This may be one important reason why, as the Canadian Bar Association notes in its "Equal Justice" report, "the justice system does not recognize or understand the social and personal realities of the people living in marginalized conditions progressing through it." 30

So how can people working within the justice system learn with and from people who have been impacted by the system? The Wahkohotwin experience suggests that an important place to start is through building respectful relationships and considering the importance of reciprocity and mutual benefit. $^{31}$ This can take time and "long-haul" commitment. ${ }^{32}$ Along with the centrality of relationships and commitment to mutual benefit at the heart of our Wahkohtowin class model is the importance of location/place. We very purposely chose not to hold the Wahkohtowin class on campus at the university but, rather, met each week at a community enterprise centre called Station 20 West. ${ }^{33}$ This centre is located in the heart of one of Saskatoon's core neighbourhoods, a neighbourhood that was accessible to members of the class who might find the journey across the river to the university campus challenging. By meeting in a space where community members felt comfortable, we were able to reflect from a critical distance on both dominant knowledge practices within the "ivory tower" and the criminal justice system and consider more closely the struggles for justice that were ongoing in the community. We reflected on how cities have been sites of assimilation and oppression for Indigenous people and how urban centres like Saskatoon exist on Indigenous land. ${ }^{34}$

27 Mallory Hendry, "Law Student Survey Raises Red Flags about Access to Legal Education," Canadian Lawyer Magazine (22 September 2014), online: <http://www.canadianlawyermag.com/5287/Law-student-survey-raises-red-flags-overaccess-to-legal-education.html $>$.

28 Darcel Bullen \& Lorne Sossin, “A Flex Time JD: New Approaches to the Accessibility of Legal Education," Canadian Bar Review (7 February 2017), online: <https://papers.ssrn.com/sol3/papers.cfm?abstract_id=2913006

29 Elizabeth L MacDowell, "Law on the Street: Legal Narrative and the Street Law Classroom" (2007-2008) 9 Rutgers Race \& L Rev 285 at 316.

30 Canadian Bar Association, "Equal Justice: Balancing the Scales" (November 2013) at 18, online: $<$ https://www.cba.org/CBAMediaLibrary/cba_na/images/Equal\%20Justice\%20\%20Microsite/PDFs/EqualJusticeFinalRe port-eng.pdf $\geq$.

31 I am grateful to Maria Campbell for conversations and teachings about reciprocity.

32 See Susan Bennett, "On Long-Haul Lawyering” (1998) 25 Fordham Urb LJ 771.

33 See Station 20 West, supra note 4.

34 See e.g. Nicholas Blomley, Unsettling the City: Urban Land and the Politics of Property (New York: Routledge, 2004) at 114. See also generally Jay T Johnson, "Dancing Into Place: the Role of the Powwow within Urban Indigenous Communities" in Evelyn Peters \& Chris Anderson, eds, Indigenous in the City: Contemporary Identities and Cultural Innovation (Vancouver: UBC Press, 2013) 216. 
In the Wahkohtowin class, learning together in the place of a community centre in the midst of a resilient, but struggling, neighbourhood allowed us to consider the ways that law and the formal criminal justice system are profoundly shaped by place and perspective despite ongoing avowals of objectivity, neutrality, placelessness, and "point-of-viewlessness." ${ }^{35}$ Indeed, as I discuss below, a key insight that emerged from the Wahkohtowin class was that relationships, location, and place matter deeply for considerations of justice and access to justice.

\section{LAW, JUSTICE, AND INTERPRETIVE COMMUNITIES}

The participants in the Wahkohtowin class were former gang members, Indigenous high-school students, Indigenous and non-Indigenous (white, Chinese, and South Asian) university students from three different disciplines, and four facilitators working in different disciplines. It perhaps goes without saying that this group in the usual course of things would not come together as fellow learners - as a particular interpretive community. To the contrary, in the usual course of things, members of the class were separated through structures of classism, racism, and settler colonialism. ${ }^{36}$ These barriers manifest in multiple and complex ways, including through the high tuition costs of university, the geography of the city and urban spaces, and the over-policing and over-incarceration of Indigenous people in Saskatchewan.

Together we discussed, analyzed, and evaluated legal texts and the system in which they are deployed using the grounded, lived experiences of people in the room to guide our interpretations. Our readings and understandings as a result were inextricable from lived experiences and, particularly, from the lived experiences of members of our class who had experienced directly the force of these legal texts as they are taken up and deployed by legal agents including police, lawyers, judges, and prison officials. As one of the law students remarked, the former gang members in the class "generalized" from "lived experience and brought really important situatedness to that text to interpret it. The approach was to interpret the text from the question of "how will this affect people in my community?" Karin Littau has reminded us that reading is a concrete bodily act, and, in the Wahkohtowin classroom, this embodied and emplaced nature of reading was brought to the fore. ${ }^{37}$ Indeed, sitting together with people who had experienced pain through the operation of the legal texts we read meant that it was impossible for the class to accept that legal interpretation can be a neutral or disembodied activity. Rather, bodies, pain, resistance, stories, and relationships were integral to our interpretation, analysis, and understanding of the texts. As I will discuss in this section, the emplaced and embodied approach to reading and learning together deeply influenced the insights about the legal texts and the criminal justice system in our class and led us to a serious consideration of the violence maintained and unleashed by this system. It also provided a critical vantage point from which to consider law's dominant interpretive community.

35 See MacDowell, supra note 29 at 208. See also Nicholas Blomey, "Introduction: the Place of Justice" in Law Commission of Canada, ed, The Place of Justice (Halifax: Fernwood Halifax, 2006) 7 at 7.

36 For a discussion of the operation of settler colonialism in Canada, see Isabel Altamirano-Jimenez, Indigenous Encounters with Neoliberalism: Place, Women, and the Environment in Canada and Mexico (Vancouver: UBC Press, 2013) at 3134. See also Monchalin, supra note 1 at 69-78.

37 Karin Littau, Theories of Reading: Books, Bodies and Bibliomania (Cambridge: Polity Press, 2006) at 2. 
Various scholars have pointed out that the identity of the community reading a text determines the community's interpretation of that text. Stanley Fish, perhaps the most famous proponent of the concept of interpretive communities, wrote: "[T]here is no single way of reading that is correct or natural, only 'ways of reading' that are extensions of community perspectives." 38 Similarly, Deborah Britzman has reminded us that there are "no innocent, normal, or unmediated readings" of texts. ${ }^{39}$ Ian Johnstone explains that meaning is produced "by neither the text nor the reader but by the interpretive community in which both are situated." ${ }^{40}$ He notes therefore that "texts do not have properties before they are encountered in situations or fields of practice; the meanings that they have are always a function of the circumstances in which they are encountered." $" 41$

From the vantage point of the Wahkohtowin classroom, law's dominant interpretive community and its methods of approaching law became visible in a troubling way. It became clear that those who professionally make and interpret the law and, indeed, claim a monopoly on legal knowledge (legislators, judges, most legal academics, most lawyers) were quite disconnected from important knowledge and experience held by members of our class. ${ }^{42}$ For example, where STR8 UP members could speak with deep understanding of the links between colonialism and intergenerational trauma and their encounters with law and the criminal justice system, it appeared to us that most of the legal texts were not informed by a deep understanding or concern with these issues. From our contextual and embodied location as readers in the Wahkohtowin class, we were able to observe how law's dominant interpretive community is always situated in a particular context and place. We were able to see that legal reading and interpretation, despite persistent appeals to neutrality and objectivity, are never innocent activities. ${ }^{43}$ Indeed, our contextual readings of the texts, which are informed deeply by personal experiences and the wider contexts in which we have located ourselves, are sharply different from the dominant "legal" approaches to reading and understanding legal texts, which too often tend to be disembodied, decontextualized, instrumentalist, and technical. ${ }^{44}$

Karin Littau argues that all texts contain "an implied reader," and it seems clear that the implied readers of the legal texts we read were never the subjects of these texts: the person panhandling, the person subjected to solitary confinement, the person standing before a judge awaiting sentence. ${ }^{45}$ Rather, the texts were written to be read, interpreted, and mobilized by people charged with managing and regulating such people, constructing them implicitly as "other." When we discussed the panhandling

38 Stanley Fish, Is There a Text in This Class? The Authority of Interpretive Communities (Cambridge, MA: Harvard University Press, 1980) at 16.

39 Deborah P Britzman, "Is There a Queer Pedagogy? Or, Stop Reading Straight" (1995) 45 Educational Theory 151 at 164.

40 Ian Johnstone, The Power of Deliberation: International Law, Politics and Organizations (New York: Oxford, 2011) at 35 .

$41 \quad$ Ibid at 36.

42 See Bridgette Dunlap “Anyone Can 'Think Like a Lawyer': How the Lawyers' Monopoly on Legal Understanding Undermines Democracy and the Rule of Law in the United States" (2014) 82 Fordham L Rev 2817.

43 Marco Wan, "Introduction" in Marco Wan, ed, Reading the Legal Case: Cross-Currents between Law and the Humanities (New York: Routledge, 2012) 1 at 3 [Wan, "Introduction"].

44 See Michael J Higdon, "The Legal Reader: An Expose" (2013) 43 NML Rev 77; Philip Kissam, The Discipline of Law School (Durham, NC: Carolina Academic Press, 2003) at 33; Wan, "Introduction," supra note 43 at 3; MacDowell, supra note 29 at 285.

45 Littau, supra note 37 at 127. 
bylaw, for example, our focus turned to the specifics of the way the bylaw created a situation where people who were panhandling were rendered "out of place," representing a threat to the dominant order of the city and further marginalized as a result of the bylaw. ${ }^{46} \mathrm{We}$ discussed how, in practice, the bylaw is mobilized in a troubling context of police harassment of Indigenous people and a larger history of ongoing attempts to remove Indigenous bodies from white urban and commercial spaces. ${ }^{47}$

Similarly, we noted that the federal statutory provisions on administrative segregation/solitary confinement (section 31 of the Corrections and Conditional Release Act) were written with a view to protecting the institution from disorder or threat that might be posed by incarcerated men or women, but not with a concern with the disorder, threat, and pain flowing from the practice of solitary confinement on the human bodies subjected to it. The text is technical, written in the detached and rational style of many statutes, appealing to the concept of "reasonable grounds." 48 Then we heard from several of the members of our group about the experience of solitary confinement: the anger, loneliness, and experience of social death. ${ }^{49}$ When read in the context of the experiences described above, the words in section 31 printed on a sheet of paper before us took on an absurd quality. The experience authorized by the text was so far from reasonable or rational or something that could be contained within a rational, administrative framework.

Sitting together in the Wahkohtowin classroom, we therefore had to confront what Robert Cover has termed "law's violence." ${ }^{50}$ Cover wrote that law and legal interpretation is always connected with pain and violence:

Legal interpretation takes place in a field of pain and death. This is true in several senses. Legal interpretive acts signal and occasion the imposition of violence upon others: a judge articulates her understanding of a text, and as a result, somebody loses his freedom, his property, his children ... Interpretations in law also continue justifications for violence which has already occurred or which is about to occur: they frequently leave behind victims whose lives have been torn apart by these organized, social practices of violence. $^{51}$

46 For critical commentary on the ways in which similar bylaws and ordinances regulate the bodies and lives of people who are homeless and marginalized, see Randall Amster, Lost in Space: The Criminalization, Globalization and Urban Ecology of Homelessness (New York: LFB Scholarly Publishing, 2008); Jamie CY Liew, "Finding Order in Calgary's Cash Corner: Using Legal Pluralism to Craft Legal Remedies for Conflicts Involving Marginalized Persons in Public Spaces” (2015) 52 Alberta L Rev 605.

47 For extensive critical commentary on this issue, see e.g. Sharene H Razack, Dying From Improvement: Inquests and Inquiries into Indigenous Deaths in Custody (Toronto: University of Toronto Press, 2015).

48 Corrections and Conditional Release Act (S.C. 1992, c. 20) at s.31(3).

49 For work on the impacts of imprisonment and solitary confinement, see Lisa Guenther, Solitary Confinement: Social Death and Its Afterlives (Minneapolis: University of Minnesota Press, 2013); Anastasia Chamberlen, "Embodying Prison Pain: Women's Experiences of Self-Injury in Prison and the Emotions of Punishment" (2015) 20 Theoretical Criminology 205.

50 Robert Cover, "Violence and the Word" (1985-1986) 95 Yale LJ 1601.

51 Ibid. 
Similarly, Rosemary Coombe has written that "[1]egal meanings are continually mobilized for the maintenance of relations of domination, and legal interpretation plays an integral part in the maintenance of social relations of inequality in our society.. ${ }^{, 52}$ This authorized violence emerged as a key theme and insight in the class, sparking a deep critique of law and legal institutions and the dominant legal interpretive community.

Our interpretations resonated with the critiques of many critical Indigenous legal scholars, who have long traced the violence of the dominant justice system and its impacts on Indigenous communities. For example, Sa'ke'j Henderson has written that "Aboriginal people brought before colonial law are brutally confronted with the racism embedded in the so-called formal legal "justice" system." $53 \mathrm{He}$ has also stated that "Canadian law was and remains the performance of an institutionalized form of colonization. It is the place in which detailed institutional arrangements of colonial society ... are made explicit and justified ... In this sense, law produces empire." ${ }^{54}$ One of the law students observed that in the Wahkohtowin class he was struck by how the violence of law was unevenly distributed. He noted that "a lot of the co-participants had stories of violence done to them by the state in particular ... which is not my experience directly and I was struck by the privilege of that position." Another law student noted that so often critiques and comments about this kind of violence are dismissed or seen as unimportant in law school - he noted that it was very different in the Wahkohtowin class where people "know what goes on." In the Wahkohtowin classroom, we could not avoid the violence authorized by law; in the way that we can in a typical law school classroom or legal arena where we are removed from the consequences and people affected. We were also able to see that knowledge practices within these dominant legal arenas are shaped by the experience and ideologies of those in the room. This meant that we could not pretend there was neutrality to law, and this required us to take a position collectively on the question of justice.

\section{IMAGINING JUSTICE TOGETHER}

From where we sat in the Wahkohtowin classroom, traditional one-way-street access-to-justice initiatives seemed ill-positioned to transform the structural and material violence maintained and produced by the criminal justice system. ${ }^{55}$ We turned our attention therefore to discussions about justice and what justice might demand of the dominant justice system and its agents. The vision articulated by members of the class was critical, politicized, and substantive. In this way, we took up critical pedagogical scholar Paolo Freire's idea that education has a vital role "in the process of denunciation of

52 Rosemary Coombe, "'Same As It Ever Was': Rethinking the Politics of Legal Interpretation” (1988-1989) 34 McGill LJ 603 at 651-652.

53 James [Sa'ke'j] Youngblood Henderson, “The Split Head Resistance: Using Imperial Law to Contradict Colonial Law for Indigenous Justice" in Elaine Coburn \& Emma LaRoque, eds, More Will Sing Their Way to Freedom: Indigenous Resistance and Resurgence (Halifax: Fernwood, 2015) at 58.

$54 \quad$ Ibid at 54.

55 For a discussion of structural violence, see Paul Farmer, "On Suffering and Structural Violence: A View from Below" (1996) 125 Daedalus 261. 
a perverse reality, as well as in that of announcing a different reality to be born from the transformed denounced reality. ${ }^{, 56}$ We embraced Freire's insistence that education can never be neutral or apolitical:

Nobody can be in the world, with the world, and with others in a neutral manner ... It is impossible to study without any commitment, as if mysteriously and suddenly we had nothing to do with the world ... In favor of what do I study? In favor of whom? Against whom do I study? ${ }^{57}$

The understanding of justice that emerged was not an abstract vision but, rather, something grounded in relationship and place. It had to do with healthy families, parents able to raise their children without fear of child apprehension, food security, safe housing, and the ability to walk on the streets without fear of police, and a society where youth have hope for the future. As one university student noted, "the kind of issues we discussed ultimately brought on ... the dignity of the human personality. We had an entry point with the justice system, but ultimately [we discussed] what it means to be human, to want to have a space of self-realization in some ways." Another noted that our discussion was "all about the community we want."

As we built relationships during the term and continued our discussions, the Wahkohtowin class participants became interested in doing a project together beyond talking. One of the STR8 UP members, who was serving his life sentence at Willow Cree Healing Lodge, had a proposal for us - that we put on a fundraiser to help the inmates' committee at Willow Cree to purchase sports equipment. The class enthusiastically supported this idea. With the support of some law students who were working on the issue of solitary confinement, the class organized a fundraising evening featuring speakers on the topic of solitary confinement and a silent auction of artwork created by men at Willow Cree. The event was a great success, raising several hundred dollars for the inmates' committee. In this way, the students in the Wahkohtowin class were able in a small way to activate their commitment to justice and continue to build solidarity and relationships in the process.

Our work of imagining together a just community and actually trying to activate a commitment to justice is quite in contrast to the dominant approach in legal education, which, as Robin West points out, tends to avoid serious conversations about justice. Indeed, West identifies this avoidance of discussions of justice as a "pathology in legal education that is indefensible." ${ }^{58}$ West's critique of the absence of serious considerations of justice in legal education can easily be applied to many mainstream, "one-waystreet" discussions about access to justice within the legal community. These discussions focus overwhelmingly on access, on mechanisms for reducing barriers to the system, on modes to educate the public about the system and its rules, and on ways to make the lawyers and other practitioners of the system more accessible to people. What is too often missing in these discussions and the models and innovations that flow from them is a serious, deep, critical engagement with what justice would look like

56 Paolo Freire, Pedagogy of Indignation (Boulder: Paradigm Press, 2004) at 72.

57 Ibid at 60.

58 Robin L West, Teaching Law: Justice, Politics, and the Demands of Professionalism (New York: Cambridge University Press, 2014) at 27. 
and what it would demand from all of us. Within the Wahkohtowin class, this discussion was central and unavoidable.

\section{CONCLUSION}

Nancy Cook has written that learning with communities may require "abandoning current notions of creating bridges solely, or even primarily, to increase the flow of access to institutionalized halls of justice." ${ }^{59}$ She writes that when lawyers or other legal system insiders build real relationships within communities "the relationships they build over time will determine their roles and what their place in the community will be." ${ }^{, 0}$ The Wahkohtowin model is one small example of an initiative that seeks to build relationships and take seriously the knowledge about law, justice, and the justice system that is held within communities. By reading and interpreting legal texts and talking about justice in the Wahkohtowin classroom, we learned about law's dominant interpretive community and confronted the violence that lies within our justice system, and we imagined together what justice would look like. While the Wahkohtowin model may not be immediately or easily transferrable into other contexts, it does suggest an approach that could be valuable to legal system insiders and community members as they struggle to work on access-to-justice issues. It suggests that relationship building and a commitment to reciprocity is important for this work. It suggests also that those working on access-tojustice issues may benefit from learning and thinking deeply with community partners about justice and then considering what this means in terms of the reconstruction of our law and justice systems. ${ }^{61}$

59 Cook, supra note 20 at 199.

60 Ibid.

61 Janice Gross Stein and Adam Cook explain the importance of the role of legal professionals in taking a key role in reconstructing law in the interests of justice. See Janice Gross Stein \& Adam Cook, "Speaking the Language of Justice: A New Legal Vernacular" in Frederick Zemens, WA Bogart \& Julia Bass, eds, Access to Justice for a New Century (Toronto: Law Society of Upper Canada, 2005) 173. 